\title{
PENGEMBANGAN PEMBERDAYAAN EKONOMI MASYARAKAT MELALUI KEGIATAN FILANTROPI (Studi Kasus Lembaga Tazakka DIII Perbankan Syariah IAIN Salatiga)
}

\author{
Qi Mangku Bahjatulloh \\ Institut Agama Islam Negeri (IAIN) Salatiga \\ bahjatulloh@gmail.com
}

\begin{abstract}
The purpose of this research is to analize general overview of the development economic empowerment of communities through philanthropy in Tazakka Instutition of Diploma III IAIN Salatiga. This research is field research based on case studies, the research done intensive, detailed and in-depth to an organization, institution or certain symptoms. Data analysis techniques used in this study is descriptive qualitative approach. The results showed that Tazakka institutions in carrying out its program of work in three main components: The spirit of giving (giving) spirit of giving aid to the needy, Spirit of Serving (service) and spirit of togetherness (associate) Tazakka to carry out activities using several stages of management, the planning stage; Organizing, Monitoring movement.
\end{abstract}

Keywords: Philanthropy, Economic Empowerment, Diploma III Islamic Banking

\begin{abstract}
Abstrak
Penelitian ini bertujuan untuk mengetahui gambaran umum pengembangan pemberdayaan ekonomi masyarakat melalui kegiatan filantropi lembaga Tazakka mahasisawa D-III Perbankan Syariah IAIN Salatigat.Penelitian ini termasuk jenis field research yang didasarkan pada studi kasus, yaitu penelitian yang dilakukan secara intensif, terinci dan mendalam terhadap suatu organisasi, lembaga atau gejala tertentu. Teknik analisis data yang digunakan pada penelititan ini menggunakan pendekatan kualitatif deskriptif. Hasil penelitian dapat diketahui bahwa Lembaga Tazakka dalam menjalankan program kerjanya dalam tiga komponen utama: Semangat memberi (giving) semangat memberi bantuan kepada kaum duafa, Semangat Melayani (service).dan Semangat kebersamaan (associate) Tazakka dalam melakukan kegiatan menggunakan beberapa tahapan manajeman, tahap perencanaan; Pengorganisasian, pergerakan Pengawasan,
\end{abstract}

Kata Kunci: Filantropi, Pemberdayaan Ekonomi, DIII Perbankan Syariah Permalink/DOI: http://dx.doi.org/10.18326/infs13.v10i2.473-494 


\section{Pendahuluan}

Ketimpangan ekonomi, penguasaan alat-alat produksi di kalangan kaum the have, menjadikan jurang ekonomi yang dalam antara si kaya dan si miskin, ketimpangan distibusi kekayaan diakibatkan kerakusan sistem ekonomi yang berpihak pada pemilik modal dan menyengsarakan masyarakat. Akibatnya kezaliman ekonomi semakin meluas, akhirnya kekuatan segelintir konglomerat mampu menguasai ekonomi mayoritas masyarakat Indonesia.

Kesadaran akan kondisi ekonomi dan politik Indonesia memunculkan gagasan untuk membangun Indonesia dengan pilantropi berbasis dana zakat, infaq, sedekah dan wakaf. Hal ini diyakini bahwa dana filantropi dapat berkontribusi secara positif bagi pembangunan ekonomi Indonesia. Meskipun hadirnya lembaga filantropi belum secara signifikan memberikan andil dalam pengentasan kemiskinan, namun setidaknya program-program berbasis dana filantropi ini secara nyata sudah dirasakan manfaatnya oleh masyarakat miskin dan rentan.

Respon masyarakat Indonesia terhadap permasalahan kemiskinan dalam bentuk pemberian telah tercatat dalam sejarah dimana meraka telah menjalankan tradisi memberi sejak lama sejak sebelum mengenal kajian-kajian ilmiah mengenai masalah kemiskinan.

Kegiatan masyarakat dalam semangat memberi antar sesama telah diwujudkan dalam berbagai bentuk, tentu tidak hanya terbatas dalam bentuk uang atau barang melainkan juga pekerjaan usaha menolong meringankan beban orang miskin serta meningkatkan kesejahteraannya disebut sebagai filantropi. Menurut Midgley (1995) dalam (Tamim, 2011), filantropi merupakan salah satu pendekatan dari tiga pendekatan untuk mempromosikan kesejahteraan termasuk di dalamnya upaya pengentasan kemiskinan yaitu pendekatan social service (social administration), social work dan philanthropy. Filantropi sebagai salah satu modal sosial telah menyatu di dalam kultur komunal (tradisi) yang telah mengakar sejak lama khususnya di masyarakat pedesaan. Fakta kultural menunjukkan bahwa tradisi filantropi dilestarikan melalui pemberian derma kepada teman, keluarga, dan tetangga yang kurang beruntung. Ciri lainnya 
ditunjukkan dengan tuntutan masyarakat untuk memprioritaskan tujuan meringankan beban orang miskin yang jumlahnya naik 1 hingga 48\% selama krisis ekonomi yang melanda Indonesia sejak tahun 1997.

Perkembangan Lembaga filantropi Islam yang sedang berlangsung di Indonesia menjadi menarik untuk di kaji dan dianalisa lebih mendalam. Tersimpannya potensi sosial-ekonomi di Indonesia yang terus berlangsung akan menjadi magnet dalam mengekplorasi program-program filantropis. Realita yang tidak dapat dipungkiri bahwa Indonesia sebagai salah satu negara yang berpenduduk kurang lebih berjumlah 237 juta penduduk masih terlampau banyak penduduk Indonesia yang hidup dibawah kondisi kurang mendapatkan keberuntungan (miskin). Menurut data Badan Pusat Statistik (BPS) Pada Maret 2016, jumlah penduduk miskin (penduduk dengan pengeluaran per kapita per bulan di bawah Garis Kemiskinan) di Indonesia mencapai 28,01 juta orang (10,86 persen), berkurang sebesar 0,50 juta orang dibandingkan dengan kondisi September 2015 yang sebesar 28,51 juta orang (11,13 persen), meski secara prosentase ada penurunan tingkat kemiskinan dari tahun 2015 hingga 2016 sebesar 0,50, namun kondisi ini tetap menjadi masalah yang harus diselesaikan oleh semua penggiat filantropi di Indonesia.

Menurut Abidin (2012) gerakan filantropi saat ini masih identik dengan upaya penguatan modal sosial dan pemberdayaan masyarakat. Gerakan tersebut merupakan respon dari realisasi pembangunan pro rakyat yang selama ini belum optimal dilakukan oleh pemerintah. Bahkan, penyelesaian masalah-masalah sosial masih terselesaikan dipermukaan saja, bukan pada akar permasalahannya.

Hadirnya organisasi atau lembaga filantropi mampu menjawab problematika program pemerintah yang sifatnya temporer. Masih banyak penggiat filantropi yang telah mempunyai status social dan jabatan strategis, berlimang harta namun masih membutuhkan akan kenikmatan hubungan sosial kemasyarakatan. Kebutuhan sosial inilah yang diwujudkan dalam kegiatan filantropi.

Selanjutnya, ketertarikan fenomena perkembangan lembaga filantropi di Indonesia mengantarkan penelitian ini untuk mengkaji 
lebih dalam kegiatan filantropi lembaga Tazakka yang dilakukan Mahasiswa DIII Perbankan Syariah IAIN Salatiga untuk pemberdayaan ekonomi masyarakat.

\section{Konsep Filantropi}

Secara estimologi, makna filantropi (philantropy) adalah kedermawanan, kemurahatian, atau sumbangan sosial; sesuatu yang menunjukkan cinta kepada manusia (Echols dan Shadly, 1995). Istilah ini berasal dari bahasa Yunani, yaitu philos (cinta) dan antrhopos (manusia), yang secara harfiah bermakna sebagai konseptualisasi dari praktek member (giving), pelayanan (service) dan asosiasi (association) dengan sukarela untuk membantu pihak lain yang membutuhkan sebagai apresiasi cinta (Chaidier, 1995).

Definisi filantropi berasal dari Philanthhopy: Philos (cinta) dan anthropos (manusia). Lebih jauh lagi konseptualisasi filantropi adalah praktik giving, services, dan association secara sukarela untuk membantu pihak lain. Bahkan bisa dimaknai Voluntary action for the public good atau tindakan sukarela untuk kepentingan publik. Filantropi sendiri hadir dari semangat untuk mendayagunakan dan menumbuhkan kemandirian civil society. Filantropi dalam sejarah kelahirannya sampai de-ngan sekarang berkembang dalam 2 (dua) varian besar yakni filantropi tradisional dan filantropi keadilan sosial (Prihatna, 2005). Hal ini pula di tegaskan oleh Allien Shaw bahwa filantropi bukanlah sekedar karitas, akan tetapi lebih pada pendampingan yang bersifat pemberdayaan berdampak jangka panjang (Latief, 2010). Universalitas konsep filantropi tidak dapat dipungkiri berdampak pada praktik-praktik filantropi yang ada di masyarakat. Begitupun dengan pemahaman filantropi dalam perspektif agama yang kemudian menambah dimensi baru implementasi filantropi keagamaan. Selanjutnya konsep filantropi tidak hanya semata-mata bersinggungan dengan material saja, W.K. Kellog Foundation mendefinisikan secara luas konsepsi filantropi yakni memberikan waktu, uang, dan pengetahuan bagaimana cara mengembangkan kebaikan bersama (Latief, 2010). Artinya keterlibatan secara luas seluruh aktifitas manusia dalam berbagai bidang dengan penuh kerelaan, partisipasi, dedikasi, gagasan, 
waktu luang, kontribusi materi merupakan bagian yang tidak dapt dipisahkan dari konsepi filantropi.

Gagasan Helmut K. Anheier dan Diana Laet tentang 'creative philanthropy' patut diapresiasi sebagai analisis pendekatanpendekatan filantropi yang cukup tepat dalam kondisi masyarakat modern (Latief, 2010). Pertama, pendekatan karitas (charity approach), pendekatan ini cenderung menyoroti gejala-gejala dari problem social daripada akar permasalahannya sehingga dampaknya tidak begitu terasa bahkan hanya temporer. Kedua, pendekatan 'filantropi ilmiah' (scientific philanthropy) yang betujuan untuk menyelesaikan masalah-masalah sosial dari penyebabnya. Akan tetapi, pendekatan ini sering gagal karena terfokus dalam analisis pendidikan dan riset semata, sehingga kemampuan untuk melihat seberapa lama, seberapa besar biaya, seberapa kompleks sering diabaikan, artinya dalam sisi praktis sering diabaikan. Ketiga, pendekatan 'new scientific philanthropy' atau neo filantropi ilmiah, pendekatan ini lebih menekankan pada proses bukan peran, dan kurang memperhatikan nilai-nilai unik lembaga filantropi yang ada dan membedakan dengan lembaga lain.

Pembahasan tentang filantropi Islam seharusnya tidak terlepas dari perkembangan konsepsi filantropi pada umumnya. Namun lebih khusus makna filantropi Islam sendiri didasari pada hal-hal di bawah ini (Prihatna, 2005):

a. Tidak ada satu dikotomi antara usaha-usaha spiritual dengan material dalam kehidupan manusia.

b. Menjadi karakter, tujuan, dan fungsi komunitas muslim (relevan makhluk sosial).

c. Konsep trusteeship mengenai kekayaan dan property.

Penelitian Abidin (2012) tentang Manifestasi dan Latensi Lembaga Filantropi Islam dalam Praktik Pemberdayaan Masyarakat: studi di Rumah Zakat Kota Malang, mampu mengungkap secara detail fungsi manifest dan laten Rumah Zakat sebagai lembaga filantropi Islam dalam praktik pemberdayaan masyarakat. Demikian juga penelitian Nasrullah (2015) Pengelolaan Dana Filantropi Untuk Pemberdayaan Pendidikan Anak Dhuafa (Studi Kasus Pada BMH Cabang Malang Jawa Timur). Mencoba 
menganalisa bagaimana Baitul Mal Hidayatullah (BMH) cabang Malang mengelola dan mendistribusikan dana filantropi (zakat, infaq, șadaqah dan wakaf) untuk pemberdayaan pendidikan anak masyarakat miskinHasil penelitian menunjukkan bahwa dana filantropi yang telah dikumpulkan oleh BMH Cabang Malang akan didistribusikan ke dalam empat program utama, dakwah, pendidikan, sosial dan ekonomi. Pengelolaan dana filantropi untuk pemberdayaan pendidikan anak miskin didistribusikan pada tiga program: Berpadu (Beasiswa Peduli Anak Dhuafa), PPAS (Pusat Pengembangan Pendidikan Anak Sholeh), dan PSD (Pengembangan Sekolah Dhuafa)

Sedangkan dalam penelitian yang dilakukan oleh Piliyanti (2010) tentang Transformasi Tradisi Filantropi Islam : Studi Model Pendayagunaan Zakat, Infaq,

Sadaqah WakafDiIndonesia. MenemukanbahwaKelembagaan Filantropi Islam di Indonesia diawali oleh dua institusi kegamaan di Indonesia, yakni Masjid dan Pesantren. Model pendayagunaan dana-dana filantropi Islam yang terdiri dari zakat, infaq, sadaqah serta wakaf masih bersifat konsumtif tradisional. Jika dana ZIS habis didistribusikan bagi mustahik. Maka, pendayagunaaan wakaf masih sebatas pada pengelolaan barang tidak bergerak (tanah) sehingga pemanfaatannya masih tradisional; kuburan, masjid, panti asuhan. Kedua, setelah pemerintah mengeluarkan undang undang tentang pengelolaan zakat dan wakaf (UU No. 38/1999 dan UU No. 41 tahun 2004), maka tatanan tradisi filantropi Islam di Indonesia mengalami babak baru. Dari sisi kelembagaan, pengelolaan dana ZISWAF lebih terarah dan terukur dengan mangadopsi unsur-unsur manajemen lembaga modern. Ogranisasi Pengelola Zakat terdiri dari BAZ dan LAZ. Serta nadzir wakaf berada dalam pengelolaan Badan Wakaf Indonesia. Dari sisi model pendayagunaan dana ZISWAF, juga telah mengarah kepada program pemberdayaan untuk mengatasi permasalah umat; kemiskinan disegala bidang (ekonomi, kesehatan, pendidikan, kerusakan lingkungan). Dengan demikian, tujuan zakat akan tercapai. Khususnya di Indonesia, pengentasan kemiskinan merupakan sebuah keniscayaan. 
Kasdi (2016) dalam penelitiannya tentang Filantropi Islam untuk Pemberdayaan Ekonomi Umat (Model Pemberdayaan Ziswaf di BMT se Kabupaten Demak) mengungkap bahwa Potensi pengembangan filantropi Islam sangat besar dalam bentuk kedermawanan umat Islam melalui zakat, infak, shadaqah, dan wakaf. Hasil survei menunjukkan bahwa hampir semua masyarakat Muslim Indonesia (99\%) pernah berderma.

Selain itu Tamin (2012) juga melakukan kajian penelitian Peran Filantropi Dalam Pengentasan Kemiskinan di dalam Komunitas Lokal, mencoba mengungkap bagaimana kontribusi filantropi di dalam meningkatkan kesejahteraan. di Desa Sukoreno Kecamatan Umbulsari Kabupaten Jember. Dengan pendekatan kualitatif, dan pengumpulan data meggunakan teknik observasi non partisipasi, wawancara mendalam, dan dokumentasi, Penelitian ini menunjukkan bahwa filantropi yang dilakukan oleh petani jeruk terhadap keluarga miskin baik yang berupa karitas maupun pemberdayaan sera penyediaan sumber-sumber produksi mempunyai kontribusi terhadap peningkatan kesejahteraan.

\section{Filantropi dalam Islam}

Islam sebagai agama yang Humanis dan rabmatan li al-ālamīn menampilkan dirinya sebagai agama yang berwajah filantropis. Wujud filantropi ini digali dari doktrin keagamaan yang bersumber dari Alquran dan Hadits yang dimodifikasi dengan perantara mekanisme ijtihad sehingga institusi zakat, infaq, sedekah dan wakaf muncul, tujuannya adalah agar harta tersebut tidak hanya berputar pada orang-orang yang memiliki kaya saja, namun juga semua lapisan merasakan putaran uang tersebut. Dalam arti yang lebih luas, perluasan dan percepatan perputaran uang merupakan representasi dari kegiatan ekonomi dan sosial lainnya, oleh karena itu dalam Islam dikenal dua cara dalam pendistribusian harta yakni yang hukumnya wajib dan sunah.

Filantropi Islam bersumber dari al-Qur'an, Surat al-Ma'ûn: 1-7, di mana salah satu dari tanda orang yang mendustakan agama adalah tidak menyantuni anak yatim. Ayat ini berarti ada muatan 
konsep sosial keagamaan yang kemudian memunculkan perintah zakat yang mengalami dua tahap yaitu, tahap makkiyah (theologis) yang merupakan tahap pembersihan diri, dan tahap madaniyah yaitu tahap pembersihan harta dengan memberikannya kepada delapan ashnâf seperti yang terdapat dalam Q.S. At-Taubah: 60. Pada posisi inilah karitas dapat dipahami sebagai filantropi, sebab seperti kita ketahui bahwa pada dasarnya filantropi Islam sangat kental dengan sifatnya yang individual karena kaitannya dengan ibadah.(Raharjo:2003)

Jika dilihat berdasarkan sifatnya, dikenal dua bentuk filantropi, yaitu filantropi tradisional dan filantropi untuk keadilan sosial. Filantropi tradisional adalah yang berbasis karitas, praktek filantropi tradisional berbentuk pemberian untuk kepentingan pelayanan sosial, misalkan pemberian langsung para dermawan untuk kalangan miskin dalam rangka memenuhi kebutuhan sehari-hari.

Namun kelemahannya adalah tidak bisa mengembangkan taraf kehidupan masyarakat miskin atau dalam istilah sehari-hari hanya memberikan, tapi tidak memberi pancing (kail). Berbeda dengan bentuk filantropi untuk keadilan sosial (social philanthropy justice), bentuk filantropi ini dapat menjembatani jurang pemisah antara si kaya dengan si miskin. Jembatan tersebut diwujudkan dengan upaya memobilisasi sumber daya untuk mendukung kegiatan yang mengugat ketidakadilan struktur yang menjadi penyebab lenggengnya kemiskinan, dengan kata lain, filantropi jenis ini mencari akar permasalahan dari kemiskinan tersebut yakni adanya faktor ketidakadilan dalam alokasi sumber daya dan akses kekuasaan dalam masyarakat. (Kholis, 1995:65)

\section{Konsep Pemberdayaan}

Mengkaji tentang konsep pemberdayaan merupakan bagian dari upaya yang selalu dikembangkan untuk menemukan hal-hal baru dalam mengikutsertakan masyarakat dalam aktivitas pembangunan di ruang lingkup lokal meskipun ruang kajiannya bersifat makro. Pemberdayaan masyarakat sebagai manifestasi intervensi komunitas bukanlah hal baru, namun patut dipahami secara lebih luas. 
Secara etimologi, kata pemberdayaan yang berawalan, "pem", "ber" (prefiks) dan berakhiran, "an" (sufiks) berasal dari kata dasar daya. Dalam Kamus Besar Bahasa Indonesia, kata "daya" berarti kemampuan untuk melakukan sesuatu atau bertindak (Tim Penyusun Kamus Pusat Bahasa Depdiknas, 2008: 324-325).

Secara konseptual, pemberdayaan atau pemberkuasaan (empowerment) berasal dari kata "Power" (kekuasaan atau keberdayaan). Karenanya ide utama pemberdayaan bersentuhan dengan konsep mengenai kekuasaan (Suharto, 2009). Kekuasaan sering kali dikaitkan dengan kemampuan untuk membuat orang lain melakukan apa yang diinginkan, terlepas dan keinginan dan minat mereka, selanjutnya menurut Suharto dikatakan perberdayaan menunjuk pada kemampuan orang khususnya kelompok rentan dan lemah sehingga mereka memiliki kekuatan atau kemampuan dalam beberapa hal (Suharto, 2009): a). Memenuhi kebutuhan dasarnya sehingga mereka memiliki kebebasan (freedom), dalam arti bukan saja bebas dalam mengemukakan pendapat, melainkan bebas dari kelaparan, bebas dari kebodohan dan bebas dari kesakitan. b). Menjangkau sumber-sumber produktif yang memungkinkan mereka dapat meningkatkan pendapatannya dan memperoleh barangbarang dan jasa yang mereka perlukan. c). Berpartisipasi dalam proses pembangunan dan keputusan-keputusan yang mempengaruhi mereka.

Pemberdayaan pada hakekatnya adalah penguatan kemampuan, kemauan, keterampilan, keberanian, daya penafsiran, dan keterbatasan-keterbatasan yang dimiliki oleh masyarakat atau kelompok yang berada di bawah dominasi penguasa (Setiawan, 2012:274-275). Sedangkan masyarakat menurut Soekanto (2014:130131) adalah setiap kelompok manusia yang hidup dan bekerja sama cukup lama sehingga mereka dapat mengatur diri mereka dan menganggap diri mereka sebagai satu kesatuan sosial dengan batasbatas yang dirumuskan dengan jelas.

Dari pengertian diatas, pemberdayaan masyarakat (community development/empowerment) adalah suatu usaha pemberian atau peningkatan "kekuasaan" (power) kepada masyarakat yang lemah atau tidak beruntung (disadvantaged) melalui perubahan struktur 
sosial, di mana rakyat (masyarakat) mampu menguasai (berkuasa atas) kehidupannya, sehingga harkat dan martabat kehidupan masyarakat dapat berkembang ke arah yang lebih baik. Menurut Soetomo (2011:69), Posisi masyarakat yang marginal dan powerless dibuat menjadi lebih berdaya. Dengan demikian pendekatan yang digunakan disebut sebagai pemberdayaan masyarakat.

Pemberdayaan masyarakat juga diartikan sebagai upaya untuk membantu masyarakat dalam mengernbangkan kemampuan sendiri sehingga bebas dan mampu untuk mengatasi masalah dan mengarnbii keputusan secara mandiri. Dengan demikian pemberdayaan masyarakat ditujukan untuk mendorong terciptanya kekuatan dan kemampuan lembaga masyarakat untuk secara mandiri mampu mengelola dirinya sendiri berdasarkan kebutuhan masyarakat itu sendiri serta mampu mengatasi tantangan persoalan dimasa yang akan datang.

Konsep pemberdayaan memuat tiga komponen utama yaitu: a. Enabling, pemberdayaan dengan menciptakan suasana atau iklim yang berkembang. b. Empowering, pemberdayaan untuk memperkuat potensi ekonomi atau daya yang dimiliki masyarakat dalam rangka memperkuat potensi ini, upaya yang amat pokok adalah peningkatan taraf pendidikan, derajat kesehatan, serta akses terhadap sumber-sumber kemajuan ekonomi, seperti modal, teknologi, informasi, lapangan kerja dan pasar. c. Pemberdayaan melalui pengembangan ekonomi rakyat dengan cara melindungi dan mencegah terjadinya persaingan yang tidak seimbang, serta menciptakan kebersamaan dan kemitraan antara yang sudah maju dengan yang belum berkembang (Sawai, dkk, 2005:17-19).

Sedangkan dilihat dari tujuan pemberdayaan menurut (Edi Suharto, 2010:60) adalah upaya memperkuat kekuasaan masyarakat, khususnya kelompok lemah yang memiliki ketidakberdayaan, baik karena kondisi internal (misalnya persepsi mereka sendiri), maupun karena kondisi eksternal (misalnya ditindas oleh struktur sosial yang tidak adil). pemberdayaan selalu menyajikan pada kondisi keadaan atau hasil yang ingin dicapai oleh sebuah perubahan sosial, yaitu masyarakat yang berdaya, memiliki kekuasaan atau mempunyai pengetahuan dan kemampuan dalam memenuhi kebutuhan 
hidupnya baik yang bersifat fisik, ekonomi, maupun sosial seperti memiliki kepercayaan diri, mampu menyampaikan aspirasi, mempunyai mata pencaharian, berpartisipasi dalam kegiatan sosial, dan mandiri dalam melaksanakan tugas-tugas kehidupannya.

Dalam hal proses atau pendekatan pemberdayaan dapat dicapai dengan melakukan pendekatan pemberdayaan yang dapat disingkat menjadi 5P yaitu: a) Pemungkinan; b) Penguatan; c) Perlindungan; d) Penyokongan; e) Pemeliharaan (Edi Suharto, 2010: 67-68). Strategi pemberdayaan masyarakat dalam (Moh. Ali Aziz, dkk, 2009:8-9).mempunyai empat komponen utama, yaitu: a) The Growth Strategy; b) The Welfare Strategy; c) The Responsitive Strategy; d) The Integrated or Holistic Strategy .

Menurut (Wrihatnolo, dkk, 2007: 23-24) ada beberapa sasaran pokok dalam strategi pemberdayaan masyarakat yang bertujuan untuk mengurangi kemiskinan yaitu: 1). Meningkatnya aksesibilitas masyarakat miskin terhadap pelayanan dasar, terutama pendidikan, kesehatan, dan prasarana dasar termasuk air minum dan sanitasi. 2). Berkurangya beban pengeluaran masyarakat miskin, terutama untuk pendidikan dan kesehatan, prasarana dasar, khususnya air minum dan sanitasi, pelayanan KB (Keluarga Berencana) dan kesejehteraan ibu, serta kecukupan pangan dan gizi. 3). Meningkatnya kualitas keluarga miskin, ditandai dengan menurunnya beban keluarga miskin, yang dalam tahap berikutnya akan disertai dengan semakin meningkatnya penghasilan keluarga miskin. 4). Meningkatnya pendapatan dan kesempatan berusaha kelompok masyarakat miskin, termasuk meningkatnya akses masyarakat miskin terhadap permodalan, bantuan teknis, dan berbagai sarana dan prasarana produksi.

Pemberdayaan akan memberikan pengaruh yang signifikan dalam kehidupan manusia jika memiliki 3 (tiga) kontek wilayah. Ketiga konteks pemberdayaan tersebut adalah pemberdayaan ruhaniyah, pemberdayaan intelektual dan pemberdayaan ekonomi (Mahendrawati, 2001:59). 


\section{Metode Penelitian}

Jenis Penelitian

Penenlitian ini termasuk jenis penelitian lapangan (field research) yang didasarkan pada studi kasus, yaitu penelitian yang dilakukan secara intensif, terinci dan mendalam terhadap suatu organisasi, lembaga atau gejala tertentu (Arikunto, 1998: 9).

\section{Lokasi Penelitian}

Lokasi penelitian ini adalah lembaga Tazakka D-III Perbankan Syariah IAIN Salatiga. Alasan pemilihan lokasi ini dikarenakan IAIN Salatiga telah memiliki lembaga Tazakka D-III Perbankan Syariah telah melaksanakan kegiatan filantropi di lingkungan kampus.

\section{Teknik Pengumpulan Data}

Pada penelitian ini peneliti menggali data primer dan data sekunder dengan menggunakan metode: 1). Pengamatan (observasi), metoda pengamatan digunakan untuk memperoleh informasi mengenai gejala-gejala yang dalam kehidupan sehari-hari dapat diamati. Hasil pengamatan biasanya didiskusikan oleh si peneliti dengan mahasiswa yang bersangkutan untuk mengetahui makna yang terdapat dibalik gejala-gejala tersebut (Suparlan 1997: 103). 2). Wawancara, dalam hal ini Peneliti mengadakan wawancara dengan pengurus lembaga Tazakka yang berkompeten dan representatif dengan masalah yang diteliti untuk memperoleh informasi mengenai gerakan filantropi. 3). Dokumentasi, metode ini dilakukan untuk mengeksplorasi data sekunder yang dikumpulkan melalui koleksi media, arsip, dokumen dan referensi yang terkait dengan penelitian ini.

\section{Teknik Analisis Data}

Data-data yang diperoleh yang berkenaan dengan penelitian baik dari pengamatan dan wawancara maupun dokumen dipilah berdasarkan kelompoknya. Data yang sudah dikategorikan kemudian diinterpretasikan dengan model interpretasi surface structure maupun deep structure. Dari interpretasi ini kemudian dikembangkan ke interpretasi deep structure, yaitu interpretasi yang mengungkap makna-makna tersirat di balik penjelasan informan, 
maupun aktivitas-aktivitas yang dilakukan para pengurus lembaga Tazakka IAIN Salatiga.

\section{Analisis}

\section{Lembaga Tazakka Sebuah Lembaga Filantropi}

Tazakka merupakan organisasi di dalam IAIN Salatiga yang dikelola oleh mahasiswa jurusan Diploma III Perbankan Syariah. Organisasi ini adalah organisasi filantropi, mempunyai tujuan untuk melatih serta meningkatkan kepeduliaan mahasiswa terhadap sesama, warga kurang mampu (miskin) sekitar kampus dan warga Salatiga.

Lembaga Tazakka dalam menjalankan program kerjanya mendasarkan pada tiga komponen utama:

a. Semangat memberi (giving), mahasiswa program diploma III Perbankan Syariah memiliki semangat memberi bantuan kepada kaum duafa, hal ini dibuktikan dengan adanya semangat menyisihkan uang saku Rp 5000,- setiap bulan yang dikumpulkan melalui koordinator kelas, dan kemudian di kumpulkan kepada lembaga Tazakka, kemudian di didistribusikan kepada kaum duafa, berupa sembako.

b. Semangat melayani (service), Dalam proses distribusi sembako yang dilakukan oleh Lembaga Tazakka kepada kaum duafa, mahasiswa memberikan pelayanan yang optimal, yaitu dimulai dari pemilihan barang sembako yang berkualitas, dikemas dalam kemasan yang bersih dan rapi, serta mereka rela melakukan proses distribusi di daerah luar kota salatiga. Dalam memberikan sembako kepada kaum duafa mahasiswa senantiasa mengedepankan sopan santun dan tutur kata yang baik. Pendekatan humanis dan dengan mengedepankan nilainilai dakwah yang mereka bawa dengan simbol-simbol islam yang mereka kenakan mampu membuat para kaum duafa menjadi lebih cinta dekat dengan ajaran islam. Selain itu petugas Tazakka selalu memberikan pelayanan yang optimal kepada para mahasiswa yang akan memberikan dana infaq/ 
sadaqah, dengan jemput bola. Bahkan mereka siap menerima dana infaq/sadaqah kapanpun dibayarkan.

c. Semangat kebersamaan (associate), rasa sukarela untuk membantu pihak lain yang membutuhkan sebagai apresiasi cinta, senantiasa melekat kepada para mahasiswa, khususnya pengurus lembaga Tazakka. Hal ini terjadi ketika mereka melihat kondisi kaum duafa dalam kondisi membutuhkan. Semangat rasa saling mencintai terhadap sesama semakin tumbuh dihati mereka. Dalam mempersiapkan sembako bantuan, mulai dari pembelian, pembungkusan pengurus Tazakka senantiasa bersama-sama bekerja tanpa pamprih, semua mereka kerjakan tanpa ada profit sedikitpun.

Sedangkan manfaat yang di dapat mahasiswa dari kegiatan filantropi melalui lembaga Tazakka adalah tumbuhnya semangat simpati dan empati terhadap sesama, rasa kasih dan sayang terhadap sesama. Salain itu pengaruh yang secara tidak langsung adalah Kampus IAIN lebih dekat dikenal oleh masyarakat. Tentu hal ini menjadi pesona tersendiri bagi kampus IAIN Salatiga, yang mampu hadir ditengah-tengah masyarakat dalam suasana berbagi. Keyakinan masyarakat terhadap lembaga pendidikan Islam IAIN Salatiga dalam mengajarkan semangat humanis, manjadikan lembaga Tazakka dapat selalu menguatkan perannya.

\section{Analisis Praktik Penerapan Dana Infaq/Sadaqah di Lembaga Tazakka}

\section{Perencanaan}

Perencanaan adalah suatu proses dasar yang dipergunakan untuk memilih tujuan dan menentukan ruang lingkup pencapaiannya. Suatu perencanaan adalah suatu aktivitas integratif yang berusaha memaksimumkan efektivitas seluruhnya dari suatu organisasi sebagai suatu sistem, sesuai dengan tujuan yang ingin dicapai oleh organisasi yang bersangkutan. Perencanaan adalah cara terbaik untuk meningkatkan kinerja lembaga Tazakka. Hal ini mendorong orang untuk bekerja lebih keras (intensif dan tekun), terlibat bersama-sama secara langsung dalam mencapai tujuan (perilaku yang terarah) 
dan memikirkan cara terbaik untuk melakukan pekerjaan (strategi pekerjaan). Dalam perencanaan ini, lembaga Tazakka membagi menjadi tiga tahap perencanaan, yaitu: a. Pengumpulan dana, dimana setiap mahasiswa program studi DIII Perbankan Syariah di IAIN Salatiga baik semester genap dan ganjil menyisihkan uangnya sebesar lima ribu rupiah. Pengumpulan dana dilaksanakan melalui koordinator masing masing kelas yang selanjutnya dikumpulkan kepada bendahara. b. Identifikasi mustahiq, Identifikasi mustahiq dilakukan dengan koordinasi dengan Ketua RT atau RW wilayah yang ditunjuk untuk dimintai rekomendasi warganya yang benarbenar tidak mampu, target Tazakka yaitu janda tua, janda miskin, serta warga yang fakir dan atau miskin. Atau melalui rekomendasi pemuka agama setempat. c. Pengalokasian Dana, setelah proses identifikasi sudah dilaksanakan, maka tahapan perencanaan selanjutnya adalah pengalokasiaan dana yang terkumpul yang selanjutnya dibelanjakan dalam bentuk sembako, yang selanjutnya didistribusikan kepada mustahiq yang sudah ditentukan.

\section{Pengorganisasian}

Tahap pengorganisasian ini dilakukan dengan membentuk pengurus lembaga Tazakka secara periodik, khususnya bagi mahasiswa jurusan Diploma III semester 3. Pembentukan pengurus ini dilakukan secara aklamasi dan disahkan dengan Surat Keputusan Ketua Jurusan Dilpoma III Perbankan Syariah. Pembagian job description sesuai dengan tugas kepenguran masing-masing. Namun dalam hal penggalangan dana semua pengurus ikut terlibat.

\section{Pergerakan}

Proses pergerakan dijalankan setelah proses perencanaan dan pengorganisasian telah dilaksanakan, lembaga tazakka mulai menganalisis dan mengindentifikasi kebijakan infaq/sadaqah yang terdiri atas kebijakan mengenai pendataan perserta sadaqah, mekanisme penentuan jumlah sadaqah, mekanisme pengumpulan/ pemungutan sadaqah. Secara terperinci adalah sebagai berikut: a. Kebijakan pendataan dilakukan melaui komunikasi/sosialisasi, 
dalam hal ini tim pendata mendatangi mahasisawa di seluruh Jurusan D3 PS melalui koordinator kelas masing-masing. Metode ini membutuhkan SDM yang mencukupi untuk mensosialisasiakan kepada semua Mahasiswa Diploma III. b. Mekanisme penentuan jumlah infaq/sadaqah, Telah menjadi kesepakatan bahwa kegiatan Tazakka ini menghimpun uang sukarela dari seluruh mahasiswa Jurusan D3 Perbankan Syariah. Namun jumlah nominal kita batasi tidak lebih darei Rp. 5000,- hal ini dimaksudkan agar tidak memberatkan mahasiswa. c. Mekanisme pengumpulan, mekanisme pengumpulan dana dilakukan dengan layanan jemput bola malalui koordinator kelas untuk mengumpulkan dana ke bendahara Tazakka. Dalam penggalangan dana, pengurus juga memanfaatkan media sosial sebagai sarana informasi untuk mengingatkan para mahasiswa Diploma Tiga untuk membayar dana infaq/sadaqah.

\section{Pengawasan}

Pengawasan pengelolaan dana Tazakka difokuskan pada aspek legalitas pengelolaan dana infaq/sadaqah, kepatuhan pada ketentuan agama, dan ketepatan sasaran (mustahiq), dan keefektivan pengumpulan dana infaq/sadaqah. Pengawasan dapat dilakukan oleh pengurus harian, dan Ketua Jurusan Diploma Tiga Perbakan Syariah.

Keberadaan pengawasa pengelolaan dana tazakka sangat diperlukan selain untuk memberikan kontrol syariah dan pendidikan, meningkatkan kepercayaan terhadap lembaga Tazakka. Dengan begitu akan memberikan jaminan atas pengelolaan dana Tazakka sesuai dengan hukum-hukum syariah dan memberikan keyakinan bahwa personil lembaga Tazakka sebagai amil lembaga filantropi Tazakka.

Pengawasan terhadap lembaga filantropi Tazakka sesungguhnya terkait erat dengan program yang direncanakan lembaga filantropi Tazakka tersebut, karena itu inti dari tujuan pengawasan adalah menjamin tercapainya tujuan lembaga lembaga filantropi Tazakka dengan cara mengembalikan atau meluruskan berbagai penyimpangan yang tidak sesuai dengan yang diprogramkan sehingga dana lembaga filantropi Tazakka benar - 
benar bisa diberdayakan untuk ikut memberikan kontribusi masalah perekonomian yang ada saat ini.

Tujuan pengawasan untuk memperbaiki, mengurangi pemborosan uang, waktu, material dan tenaga. Di samping itu, pengawasan juga bertujuan untuk membantu menegakkan agar peraturan ditaati, sehingga dapat mencapai efisiensi yang setinggitingginya.

\section{Distribusi Pengelolaan Dana Tazakka}

Dalam menjalankan program pengelolaan dana infaq dan shadaqah, lembaga Tazakka D-III Perbankan Syariah menggunakan mekanisme distribusi sebagai mana gambar dibawah ini:

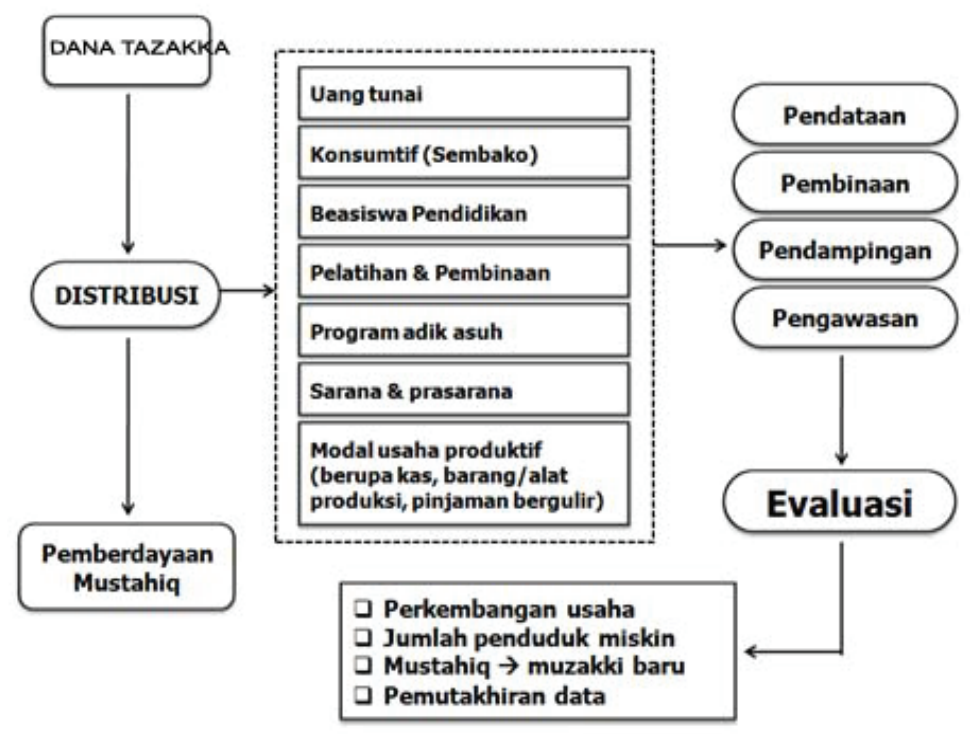

\section{Gambar 1}

\section{Model Distribusi Pengelolaan Dana Tazakka}

Dalam kebijakan distribusi dana Infaq/shadaqah ada beberapa hal yang telah direncakan, pemberian uang tunai, sembako, beasiswa, pelatihan dan pembinaan, program adik asuh, sarana dan prasarana, modal usaha. Namun yang telah kita lakukan 
dan terapkan di lapangan adalah distribusi melalui bahan pokok atau sembako. Hal itu dilakukan mengingat dana yang terkumpul relative masih kecil.

Selain itu dana infaq sadaqah yang telah terkumpul selanjutnya didistribusikan kepada para mustabiq. Penentuan mustahiq (pihak yang berhak menerima) dilakukan dengan beberapa pertimbangan. Pertimbangan yang umum dilakukan oleh pengelola antara lain : 1) Menyesuaikan dengan ketentuan dan asnaf, 2) Mengacu pada kebijakan Pembina Tazakka, 3) Berdasarkan hasil rapat dan musyawarah dan dengar pendapat pengurus Tazakka. 4) Disesuaikan dengan jumlah dana yang terkumpul.

Secara umum, kebijakan distribusi infaq/shadaqah telah mengacu pada aspek legalitas mustahiq (pihak yang berhak menerima infaq/sadaqah). Aspek penting yang perlu dipahami dan diperhatikan terkait dengan kebijakan distribusi dana infaq sadaqah yaitu ketepatan dalam menentukan mustahiq, terutama dalam mendefinisi syarat-syarat yang harus dipenuhi sebagai mustahiq. Hal ini perlu diperhatikan untuk mencapai ketepatan sasaran (mustahiq) dan ketepatan penggunaan dana infaq sadaqah.

Setelah mustabiq selesai ditentukan, selanjutnya diteruskan dengan pengalokasiaan dana Tazakka yang sudah terkumpul untuk dibelanjakan dalam bentuk sembako, masing-masing bingkisan terdapat beras seberat 5 kilogram gula 1kilogram minyak goreng 2 liter, dan sirup 1 botol.

\section{Kesimpulan}

Kesimpulan penelitian ini dapat disajikan seperti berikut: 1). Tazakka merupakan organisasi filantropi di dalam IAIN yang dikelola oleh mahasiswa jurusan Diploma III Perbankan Syariah, bertujuan untuk melatih serta meningkatkan kepeduliaan mahasiswa terhadap sesama, khususnya warga miskin sekitar kampus dan warga Salatiga umumnya yang hidup dibawah garis kemiskinan. 2). Lembaga Tazakka dalam menjalankan program kerjanya dalam tiga komponen utama: Semangat memberi (giving) semangat memberi bantuan kepada kaum duafa, hal ini dibuktikan dengan adanya semangat 
menyisihkan uang saku Rp 5000,- setiap bulan dan didistribusikan kepada kaum duafa, berupa sembako. Semangat Melayani (service). Dalam proses distribusi sembako yang dilakukan oleh Lembaga Tazakka kepada kaum duafa, mahasiswa memberikan pelayanan yang optimal. Pendekatan humanis dan dengan mengedepankan nilai-nilai dakwah yang mereka bawa dengan symbol-simbol islam mampu membuat para kaum duafa menjadi lebih cinta dekat dengan ajaran islam. Semangat kebersamaan (associate) Rasa sukarela untuk membantu pihak lain yang membutuhkan sebagai apresiasi cinta, senantiasa melekat kepada para mahasiswa, khususnya pengurus lembaga Tazakka. 3). Tazakka dalam melakukan kegiatan menggunakan beberapa tahapan, Pertama, tahap perencanaan, Dalam perencanaan ini, lembaga Tazakka membagi menjadi tiga tahap perencanaan, yaitu: Pengumpulan dana, Identifikasi mustahiq, Pengalokasian Dana. Kedua, Pengorganisasian Tahap pengorganisasian ini dilakukan dengan membentuk pengurus lembaga Tazakka secara periodik, khususnya bagi mahasiswa jurusan diploma tiga semester 3. Pembentukan pengurus ini dilakukan secara aklamasi dan disahkan dengan Surat Keputusan Ketua Jurusan Dilpoma tiga Perbankan Syariah. Pembagian job description sesuai dengan tugas kepenguran masing-masing. Namun dalam penggalangan dana semua pengurus dilibatkan. Ketiga, pergerakan yaitu dengan menganalisis dan mengindentifikasi kebijakan infaq/ sadaqah yang terdiri atas kebijakan mengenai pendataan perserta sadaqah, mekanisme penentuan jumlah sadaqah, mekanisme pengumpulan/pemungutan sadaqah. Keempat, Pengawasan, Pengawasan pengelolaan zakat difokuskan pada aspek legalitas pengelolaan dana infaq/sadaqah, kepatuhan pada ketentuan agama, dan ketepatan sasaran (muzakki), dan keefektivan pengumpulan dana infaq/sadaqah. Pengawasan dapat dilakukan oleh pengurus harian, dan Ketua Jurusan Diploma Tiga Perbakan Syariah. 


\section{Daftar Pustaka}

Aziz, Moh. Ali, dkk , 2009. Dakwah Pemberdayaan Masyarakat: Paradigma Aksi Metodologi, Yogyakarta: Pustaka pesantren

Abidin, Zaenal. 2012. Manfestasi dan Latensi Lembaga Filantropi Islam dalam Praktik Pemberadayaan Masyarakat: Studi di Rumah Zakat Malang. Jurnal Salam Vol 15 No 2

Arikunto, Suharsimi. 1998. Prosedur Penelitian (suatu pendekatan praktek), cet. 11, Jakarta : PT Rineka Cipta.

Bisri, Cik Hasan, 2004. Pilar-Pilar Penelitian Hukum Islam dan Pranata Sosial, Jakarta: PT. Raja Grafindo Persada

Chaer, Abdul. 2007. Linguistik Umum. Jakarta: Reneka Cipta

Chaider S. Bamualim dan Irfan Abubakar, 2005. Revitalisasi Filantropi Islam: Studi Kasus Lembaga Zakat dan Wakaf di Indonesia. Jakarta: Pusat Bahasa dan Budaya, Universitas Islam Negeri Syarif Hidayatullah Jakarta dan Ford Foundation

Hasibuan, Malayu S.P., 2014, Manajemen; Dasar, Pengertian, dan Masalah, Jakarta: Penerbit PT Bumi Aksara

Havinal, Veerabhadrappa, 2009. Management and Entrepreneurship, New Delhi: New Age International (P) Limited Publisher

John M. Echols dan Hassan Shadily. (1995). Kamus Inggris Indonesia. Jakarta: Gramedia

Kasdi, Abdurrahman, 2016. Filantropi Islam untuk Pemberdayaan Ekonomi Umat (model Pemberdayaan Ziswaf di BMT se Kabupaten Demak) Jurnal Iqtishadia, Vol. 9, No. 2, 2016

Kholis, Nur, 1995. Potret Filantropi Islam Potret Filantropi Islamdi Propinsi Di Propinsi Di Propinsi Di Propinsi Daerah Istimewa Yogyakarta, Jurnal La Riba Vol. VII. No 1 Juli 2003.

Kurniawati. 2004. Kedermawanan Kaum Muslimin-Hasil Survei di Sepuluh Kota. PIRAC: Jakarta. 
Latief, H. 2010. Melayani Umat: Filantropi Islam Dan Ideologi Kesejahteraan Kaum Modernis. PT Gramedia Pustaka Utama: Jakarta.

Latief, H. Filantropi Islam Dan Aktivisme Sosial Berbasis Pesantren Di Pedesaan, jurnal.umy.ac.id

Lovely Professional University (LPU), 2011. Principles and Practices of Management, New Delhi: Excel Books Private Limited

M. Dawam Raharjo, 2003. Filantropi Islam dan Keadilan Sosial: Mengurai Kebingungan Epistemologis", dalam Idris Thaha Berderma Untuk Semua: Wacana Dan Praktek Filantropi Islam, Jakarta: Teraju

Mahendrawati, Nanih, 2001. Pengembangan Masyarakat Islam, Bandung: PT. Remaja Rosdakarya

Moleong, Lexy, 2002. Metodologi Penelitian Kualitatif, Bandung: Rosda Karya.

Olum, Yasin, 2004, Modern Management Theories And Practices, Being a paper presented at the 15th East African Central Banking Course, held on 12th July 2004, at Kenya School of Monetary Studies

Piliyanti, Indah, 2010. Transformasi Tradisi Filantropi Islam: Studi Model Pendayagunaan Zakat, Infaq, Sadaqah Wakaf Di Indonesia. Jurnal Ekonomika Nomor II edisi II Nopember 2010

Prihatna, A. A. 2005. Filantropi dan keadilan sosial. Revitaliasasi Filantropi Islam. Jakarta: PBB UIN Syarif Hidayatullah dan The Ford Foundation.

Satori, Djam'an dan Komariah. 2010. Metodologi Penelitian Kualitatif. Bandung: Alfabeta.

Sawai, Jerry Joas, 2005. Pembangunan dalam Perspektif Sosiologi, Semarang: Gunungjati

Setiawan, Iwan, 2012. Dinamika Pemberdayaan Petani: Sebuah Refleksi dan Generalisasi Kasus di Jawa Barat, Bandung: Widya Padjadjaran 
Soekanto, Soerjono dkk, 2014. Sosiologi Suatu Pengantar, Cet. Ke46, Depok: PT RajaGrafindo Persada

Soetomo, 2011. Pemberdayaan Masyarakat: Mungkinkah Muncul Antitesisnya, Yogyakarta: Pustaka Pelajar

Sudjana, Nana dan Kusumah, Ahwal, 2000, Proposal Penelitian di Perguruan Tinggi, Bandung: Sinar Baru Algesindo.

Sugiyono, 2010. Metode Penelitian Kuantitatif Kualitatif dan R\&D, Alfabeta, Bandung.

Suharto, Edi, 2010. Membangun Masyarakat Memberdayakan Rakyat: Kajian Strategis Pembangunan Kesejahteraan Sosial dan Pekerjaan Sosial, Cet. Ke-4, Bandung: PT. Refika Aditama

Taylor, Frederick Winslow, 1919. The Principles of Scientific Management, New York \& London: Harper \& Brother Publisher

Tamin, Imron Hadi, 2011. Peran Filantropi Dalam Pengentasan Kemiskinan di dalam Komunitas Lokal, Jurnal Sosiologi Islam, Vol 1 No 1

Terry, George R., Leslie W. Rue, 2000. Principles of Management (Dasar-Dasar Manajemen), Terj. G. A. Ticoalu, Jakarta: PT Bumi Aksara

Tim Penyusun Kamus Pusat Bahasa Departemen Pendidikan Nasional (Depdiknas), 2008. Kamus Besar Bahasa Indonesia, Jakarta: Balai Pustaka

Wrihatnolo, Randy R. dan Rianto Nugroho D, 2007. Manajemen Pemberdayaan: Sebuah Pengantar dan Panduan untuk Pemberdayaan Masyarakat, Jakarta: PT Elex Media Komputindo

BPS 2016. Laporan Data Statistik Kemiskinan 2016. https://www. bps.go.id/brs/view/id/1229 